\title{
Regional stratigraphy, facies distribution, and hydrocarbons potential of the Oligocene strata across the Arabian Plate and Western Iran
}

\author{
Fadhil N. Sadooni ${ }^{1}$ (I) A. S. Alsharhan ${ }^{2}$ \\ Accepted: 30 July 2019 / Published online: 5 August 2019 \\ (c) The Author(s) 2019
}

\begin{abstract}
Major global events during the Oligocene epoch included a climatic change from warm "greenhouse" to a cooler "icehouse" that was accompanied by the onset of Antarctic glaciation. These events led to decline in water temperature, salinity, nutrient supply and oxygen levels, and the extinction of some major fauna and flora. Within the study area, during this epoch, the shrinkage of the Neotethys and the development of the Paratethys, the collision of Arabia with Eurasia and the development of the Zagros mountains and opening of the Red Sea which led eventually to the separation of Arabia from Africa were witnessed. Oligocene sediments are absent from most parts of the Arabian Plate but are well-preserved in western and southwestern Iran. The most well-developed strata are the coral reefs of the Kirkuk Group in northern Iraq and the shallow water carbonates of the Asmari Formation in southwestern Iran. The study area also represents the birthplace of commercial hydrocarbons production in the Middle East from these sediments in Masjid-i-Sulaiman Field in Iran and Kirkuk Field in Iraq at the first decade of the last century. Future exploration for hydrocarbons potential should focus on identifying subsurface coral buildups or clastic strata that are equivalent to the Asmari Formation in Iran.
\end{abstract}

Keywords Arabian Plate $\cdot$ Iran $\cdot$ Oligocene $\cdot$ Tertiary $\cdot$ Coral reefs $\cdot$ Hydrocarbons

\section{Introduction}

The Oligocene is established as the global epoch during which a change from global warm "greenhouse" to a cooler initial "icehouse" climate took place. It witnessed the establishment of Antarctic glaciation associated with a global decline in temperature (Kargaranbafghi and Neubauer 2017). Houben et al. (2012) established that $\delta^{18} \mathrm{O}$ isotope rations for benthic foraminifera indicated that the advent of the Oligocene was marked by the partial onset of a major glaciation period in Antarctica. In their study of paleoclimatic and paleoecologic changes across the Eocene-Oligocene boundary within the Thrace Basin of the Northeast Aegean Sea in Greece, Maravelis and Zelilidis (2012) reported that the early Oligocene was globally characterized by a decrease in water temperature, salinity, nutrient supply and oxygen

Fadhil N. Sadooni

fsadooni@qu.edu.qa

1 Environmental Science Center, Qatar University, P. O. Box 2713, Doha, Qatar

2 Middle East Geological and Environmental Establishment, P. O. Box 78830, Dubai, United Arab Emirates levels. These environmental and climatic changes triggered large-scale geologic processes that included the extinction of fauna and flora, erosion, and seal-level changes in different parts of the world (Prothero 1994; Sarkar et al. 2003; Wade and Pearson 2008; Cotton and Pearson 2011).

$\mathrm{Li}$ et al. (2018) suggested that although the Oligocene was, in general, a transitional period from a warm to a cooler climatic condition, their study of 149 macrofossil floras led them to conclude, that the middle to high latitudes areas of Eurasia were dominated by humid subtropical climatic conditions with a mean annual temperature ranging between 5.4 and $25.5^{\circ} \mathrm{C}$. They also indicated that spatial changes such as the retreat of the Paratethys, may have influenced the climatic conditions of Eurasia. Many benthic and planktonic foraminifera such as the Hantkeninidae became extinct during the Oligocene. Study has indicated that the climatic changes associated with abrupt increase in nutrient supply may have caused the extinction (Cotton and Pearson 2011). Ozsvárt et al. (2016) noted a declining level of bottom-water oxygen during the Eocene-Oligocene boundary, which was considered to have eventually led to the establishment of dysoxic conditions at the early Oligocene. They reported a deviation in 
the isotope characterization of both planktonic and benthic foraminifera, which they attributed to the combined factors of the gradual isolation of the Paratethys, the progressing Alpine orogeny and, sea-level change. Ivany et al. (2000) believed that temperature fluctuations rather than a change in mean annual temperature were the main causes of the faunal changes that happened during the same period.

According to Rögl (1998) the paleogeographic configuration of Eurasia had changed due to tectonic turnover during the Early Oligocene which, in turn had to the birth of the Paratethys and the closure of the Eastern Paratethys from the Indian Ocean. The open seaways between the Mediterranean Tethys and the Western/Central Paratethys began to narrow along the Alpinotype tectonic belts.

Regionally, the Oligocene was an epoch of great geologic events. In the Tethys region, was witnessed the gradual shrinkage of the Neotethys surface area and the development of the Paratethys. In the Zagros Mountains region, the collision between the Arabian and the Eurasian Plates was the major event that characterized that period. It led to the formation of the Bitlis suture, the Zagros and Makaran thrusts and, the subduction of the oceanic lithosphere northwards beneath the Eurasian Plate. These events were associated with the rapid exhumation of parts of the Arabian Plate and mountain building processes, (Kargaranbafghi and Neubauer 2017). The collision event also led to the opening of the Red Sea, which had begun during the Eocene. However, separation of the Arabian Plate from the African Plate occurred during the Oligocene. The start of the Gulf of Aden syn-rift also dates to that time. The opening of the Red Sea was associated with wide-scale volcanic activity in the neighboring areas of present-day Saudi Arabia (Fig. 1).
The Oligocene sediments of Arabia and western Eurasia (present-day west Iran) were the first hydrocarbon reservoirs to be exploited on commercial basis in the region. The first exploration well was drilled in Iran in 1908, in the field of Masjid-i-Suleiman penetrating the Asmari Formation (Oligocene-Miocene). In 1927, Kirkuk Oilfield was drilled on the Iraqi side and the Kirkuk-1 targeted the Kirkuk Group (Oligocene). In both formations, oil was encountered in large quantities that signaled the world's first large-scale production of hydrocarbons in the Middle East. Both sites represent important world geologic heritage sites (Habibi and Ruban 2017).

\section{Regional distribution}

Much of the Oligocene sediments in eastern Arabia were either removed or had never been deposited (Figs. 2, 3). What is left on the surface are only a few, scattered, resistive carbonate ridges, mainly in the Qarah Chauq Dagh Mountains in north Iraq and, in Jabal Hafit on the UAE-Omani borders. Subsurface Oligocene sediments were encountered in the fields of Kirkuk and Bai Hassan in north Iraq and, in the Mandous Field offshore of the UAE. Oligocene clastic sediments were also found also in the subsurface sections of a narrow strip of oilfields along the Iran-Iraq border including Buzurgan, Abu Gherab, and Majnoon. These particular strata were designated as a new stratigraphic group; the Mesan Group by Al-Siddiki (1980). This new clastic sediment group was expected to be equivalent to the carbonate Kirkuk Group (van Bellen 1956) but this assumption had not been rigorously investigated. In fact, Buday (1980) suggested that the sandy-calcareous sediments encountered in
Fig. 1 Major climatic and tectonic events that characterized the Eocene-Oligocene time in the World and the ArabianEurasian plates interface (after Kargaranbafghi and Neubauer 2017)

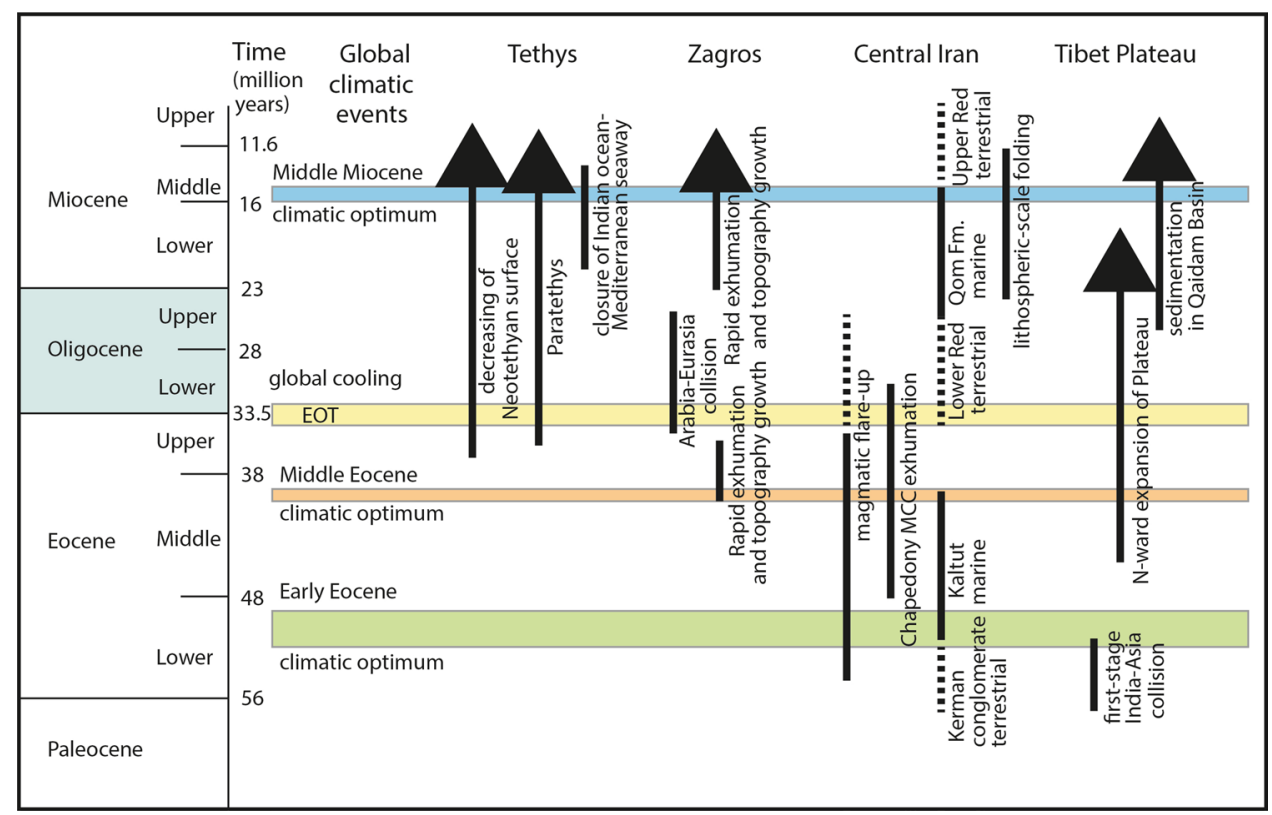


Fig. 2 Paleogeographic map of the Arabian Plate during the Oligocene (modified from Farouk et al. 2013)

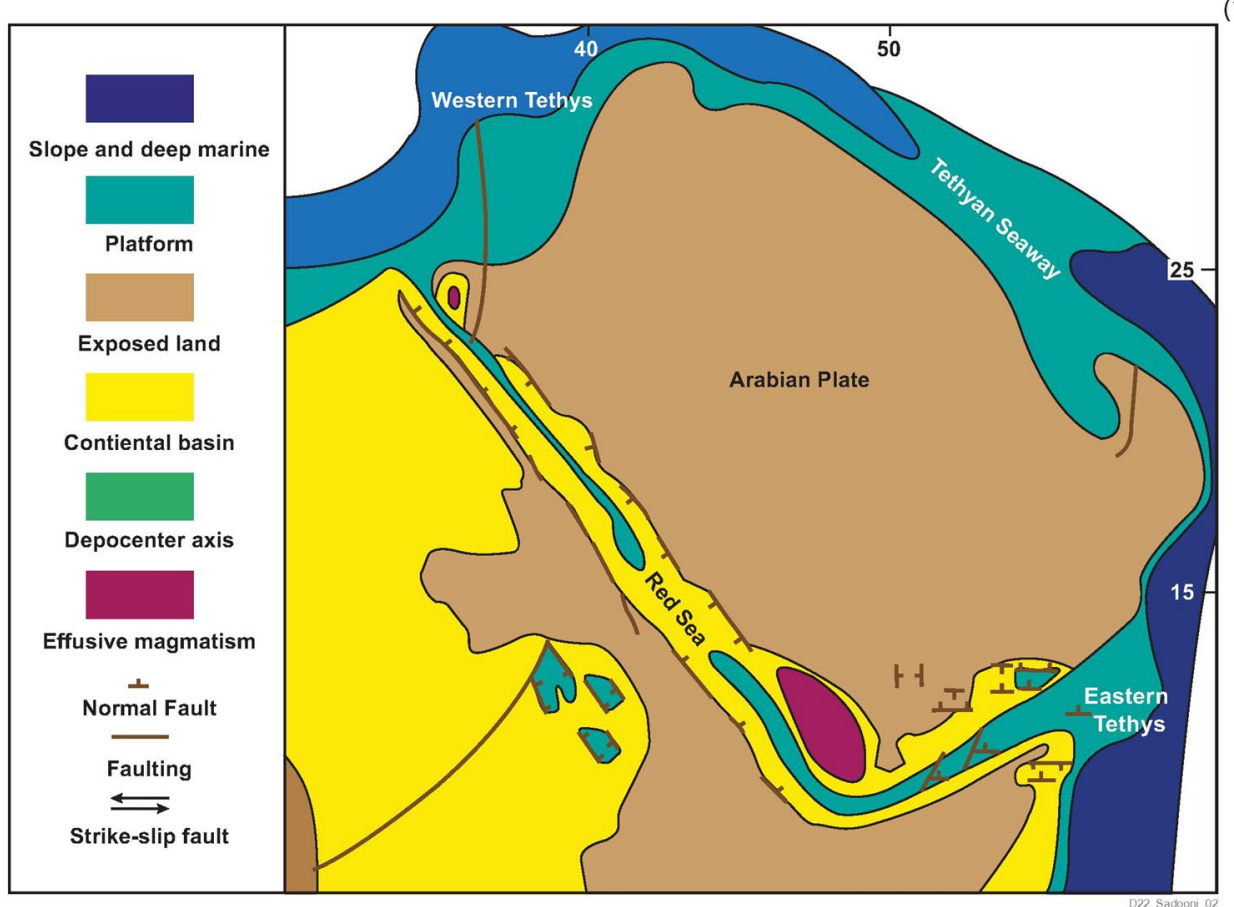

(5)

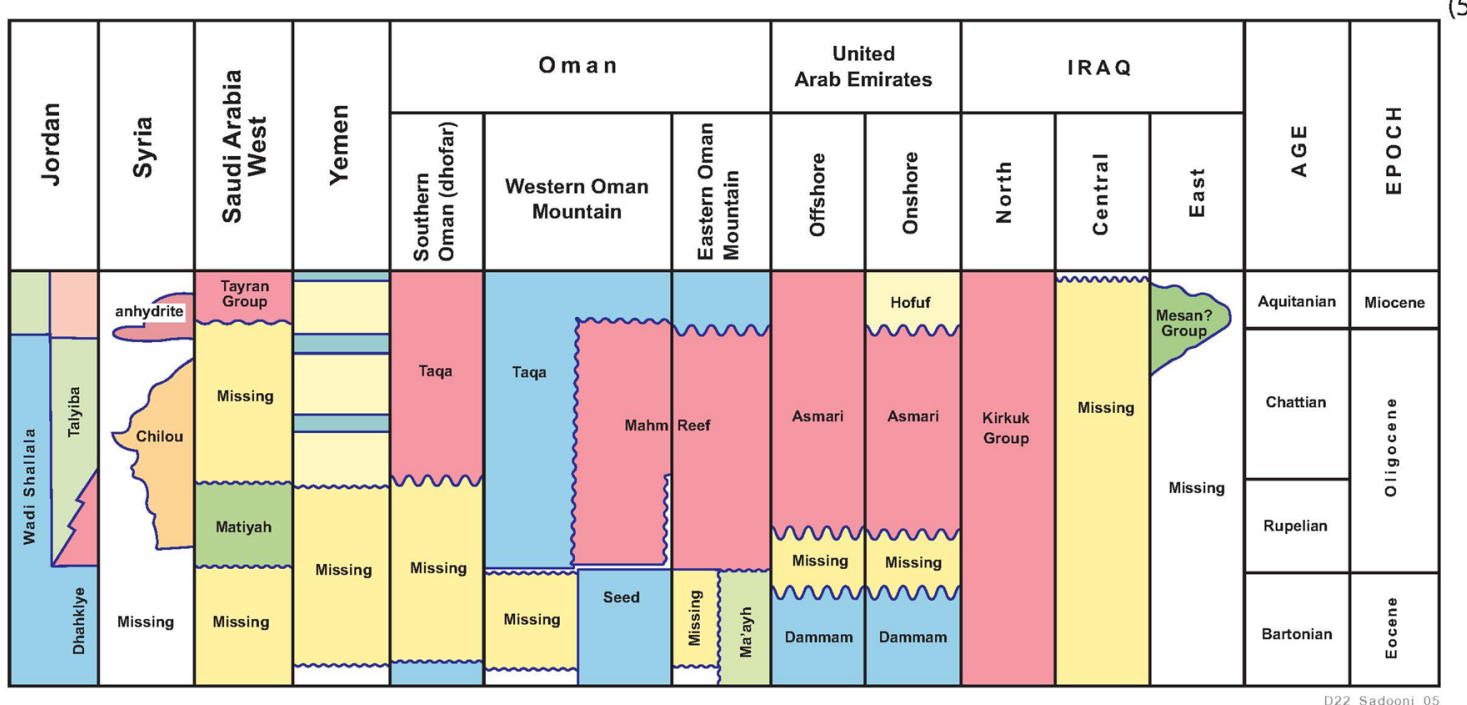

政 
Table 1 Oligocene-Miocene rock units in SW Iran and their time equivalents in $\mathrm{N}$ and $\mathrm{NE}$ Iraq (modified from Motiei 1993; Soltani et al. 2013)

\begin{tabular}{|c|c|c|c|}
\hline Age & Rocks units SW Iran & Rock units $\mathrm{N}$ and NE Iraq & \\
\hline Burdigalian & Gaschsaran & Lower Fars/Fatha & \\
\hline Burdigalian & Upper Asmari & Jeribe & \\
\hline Late Aquitanian & Upper/Middle Asmari & Jeribe and Dhiban & \\
\hline Early Aquitanian & Middle Asmari & Serikagni and Euphrates & \\
\hline \multicolumn{4}{|l|}{ Oligocene } \\
\hline Chattian & Lower Asmari and Upper Pabdeh & Arah, Azkand and Ibrahim & Kirkuk Group \\
\hline \multirow{2}{*}{ Rupelian } & & Baba, Bajwan, and Tarjil & \\
\hline & & Shurau, Sheikh Alas, and Palani & \\
\hline
\end{tabular}

$200 \mathrm{~km}$ wide. Both formations host major hydrocarbon reserves in SW Iran and northern Iraq. Definitive research on the Asmari Formation was first published by Richardson (1924) and, later revised and dated by Lees (1933) and James and Wynd (1965). The lithostratigraphy, biozones and microfacies of the formation have been studied in detail by many authors and at different localities of the Zagros Basin (e.g. Motiei 1993; Shahkarami 2013). Similarly, the Kirkuk Group encompasses the earliest recognized and most-documented Oligocene sediments in the Middle East. The Group is formed of reefal, fore-reefal and back-reef strata which have been described in some detail by van Bellen (1956) and van Bellen et al. (1959) for the oilfields of Kirkuk, Bai Hassan and, for the outcrops of the Qarah Chuaq Dagh Mountains. Before these published works, these sediments had been recognized and defined in reports of the early geologists of Iraq Petroleum Company and also in reports by its older counterparts.

In the northern extension of the Arabian Plate, Oligocene sediments are underlain by the Paleocene sub-basinal Jaddala Formation and, overlain by the Middle Miocene Lower Fars Formation which represents a lagoonal-sabkha terminal phase. In the southern parts of the Arabian Plate, the Asmari Formation is conformably overlain by early Miocene sediments and conformably underlain by Late Eocene carbonates. The base of the Asmari Formation has been characterized as conformable with the Pabdeh Formation in Fars province, while, it is diachronous in Lurestan and Khuzestan provinces (Shirazi et al. 2012).

In the southeastern parts of the Arabian Plate, Oligocene strata are exposed in Jabal Hafit near Al-Ain city and the border with Oman, UAE. They attain a thickness of up to $480 \mathrm{~m}$ and have been assigned to the Asmari Formation. They also form a persistent wedge of limestone that covers only a relatively small area. In the subsurface, Alsharhan and Nairn (1997) described some Oligocene strata in the offshore areas of Abu Dhabi. These sediments which are assigned also to the Asmari Formation consist of up to $110 \mathrm{~m}$ of dolomite and dolomitic limestone. A schematic presentation of the main facies and the geomorphic features of the Oligocene sediments in the Arabian Plate is shown in Fig. 4.

\section{Sequence stratigraphy}

The Eocene-Oligocene boundary marks the boundary between the Megasequence AP10 and AP11 (Sharland et al. 2001). The whole Oligocene succession in the Arabian Plate represents the lower part of AP11. The Pg30 Maximum Flooding Surface has been identified in some parts of the Arabian Plate but, it is missing or has yet to be found in Kuwait, Bahrain, Saudi Arabia and, Qatar. The most representative section of this MFS can be found within the Sheikh Alas Formation which is part of the Kirkuk Group in northern Iraq (van Bellen 1956; van Bellen et al. 1959; Aqrawi et al. 2010); (Fig. 5).

The Sheikh Alas Formation may be the oldest formation of the Iraqi Oligocene in the reef and fore-reef facies zone. The formation was introduced by van Bellen (1956) from its type locality that lies at the northern dome of the Qara Chauq Mountain near Sheikh-Alas village at the outskirt of Kirkuk city. In its type locality, the Formation is composed of dolomitic and recrystallized limestone. In the subsurface section, the Formation consists of marly and organic-detrital limestone with conglomerate beds at its base (Buday 1980). Only rare fossils were described from this type locality including obscured assemblages of Nummulites intermedius fichteli (van Bellen et al. 1959).

In Iran, the $\mathrm{Pg} 30$ is located within the limestone near the base of the Asmari Formation passing into the deep-water Pabdeh Formation (James and Wynd 1965). In Syria, the $\mathrm{Pg} 30$ surface was located in an undifferentiated marl unit above the Abaid Formation and at a limestone unit near the base of Chilou Formation (Jones and Racey 1994; Sharland et al. 2001). In Jordan, the Pg30 was identified at the lower part of the Tayba sandy limestone Formation in Ash Shunah and Wadi El Ghadaf formations (Farouk et al. 2013).

In UAE, the surface was identified within a bed of marls at the base of the Asmari Formation (Jones and Racey 1994; Sharland et al. 2001). In Oman, the Pg30 MFS is located in 
Fig. 4 Schematic distribution of the main facies and geomorphic features of the Oligocene sediments in the Arabian Plate (modified from Jones and Racey 1994; Alsharhan and Nairn 1997)

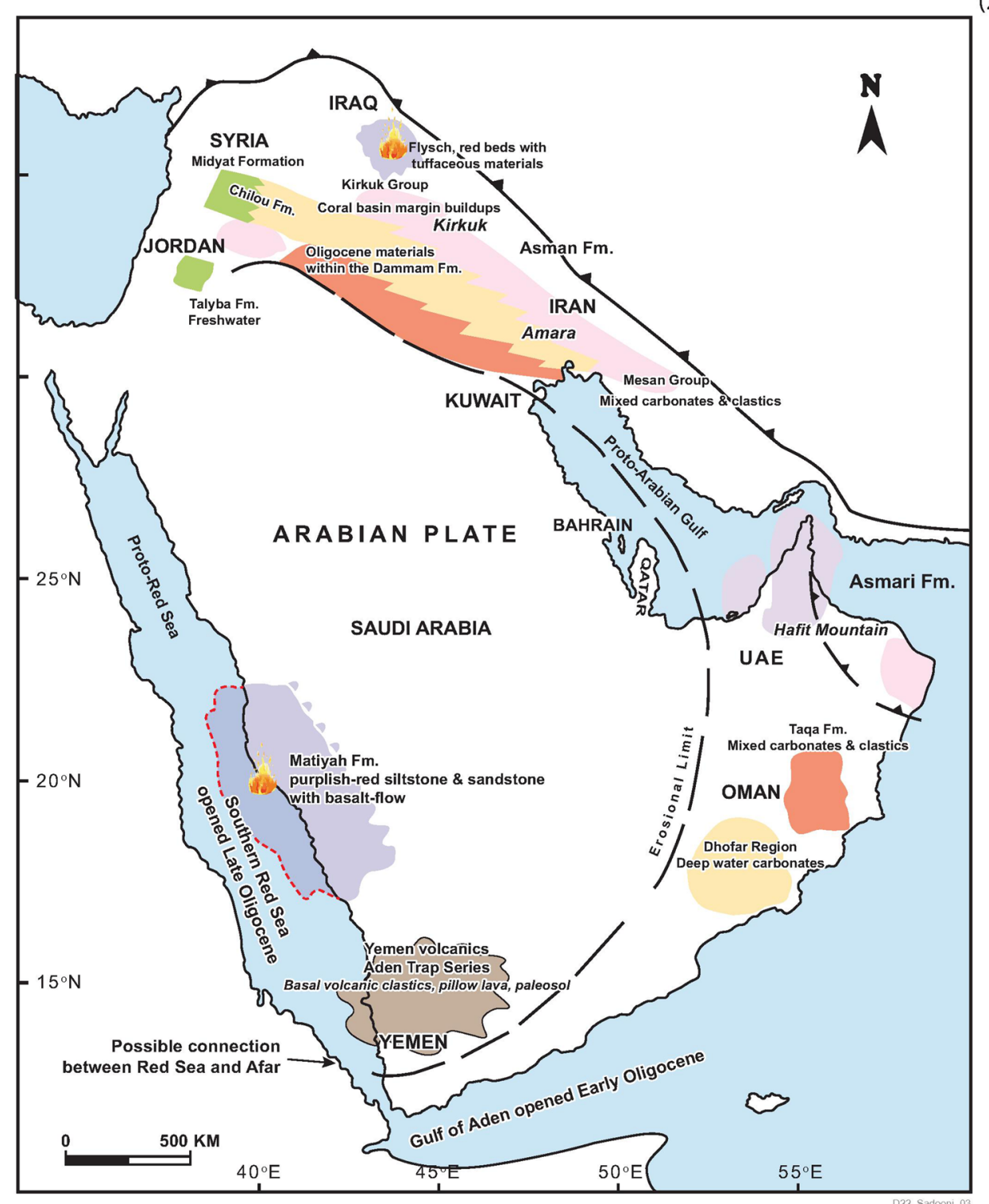

the limestone near the base of the Taqa Formation (HughesClarke 1988), gradually changing into shale at the base of the Fars and Mughsayl formations (Roger et al. 1989; Sharland et al. 2001), toward south Oman. In Yemen, the same surface was found in the limestone near the base of the Shihr Group (Taqa Formation) (Ellis et al. 1996; Beydoun and Greenwood 1968, Beydoun 1988; Sharland et al. 2001).

\section{Sedimentary facies}

In some deeper parts of the Neotethys basin, where sediments were deposited and preserved, the Oligocene depositional system was a continuation of that of the Eocene. The newly rising Zagros-Taurus Mountains in the northeast parts of the Arabian Plate continued to provide a source of clastic materials. The crustal shortening associated with the formation of these mountains created many depressions into which either flysch sediments or deep-water carbonates accumulated. Filled basins were topped by red beds with some volcanic materials. In the meantime, coral reefs started to colonize the recently formed rises forming basin-margin buildups associated with coralline algae and bryozoans as in northern Iraq, southwestern Iran, Oman and the United Arab Emirates. During the early Oligocene, the Gulf of Aden syn-rift started to form while the southern part of the Red Sea started to open during the Late Oligocene. Basalt flow was reported from the Oligocene Matiyah Formation in western Saudi Arabia and also, volcaniclastic pillow lava was found within the Aden Trap Series in Yemen. Paleosoils 
Fig. 5 Sequence stratigraphy of the Oligocene strata in the Arabian Plate (modified from Sharland et al. 2001)

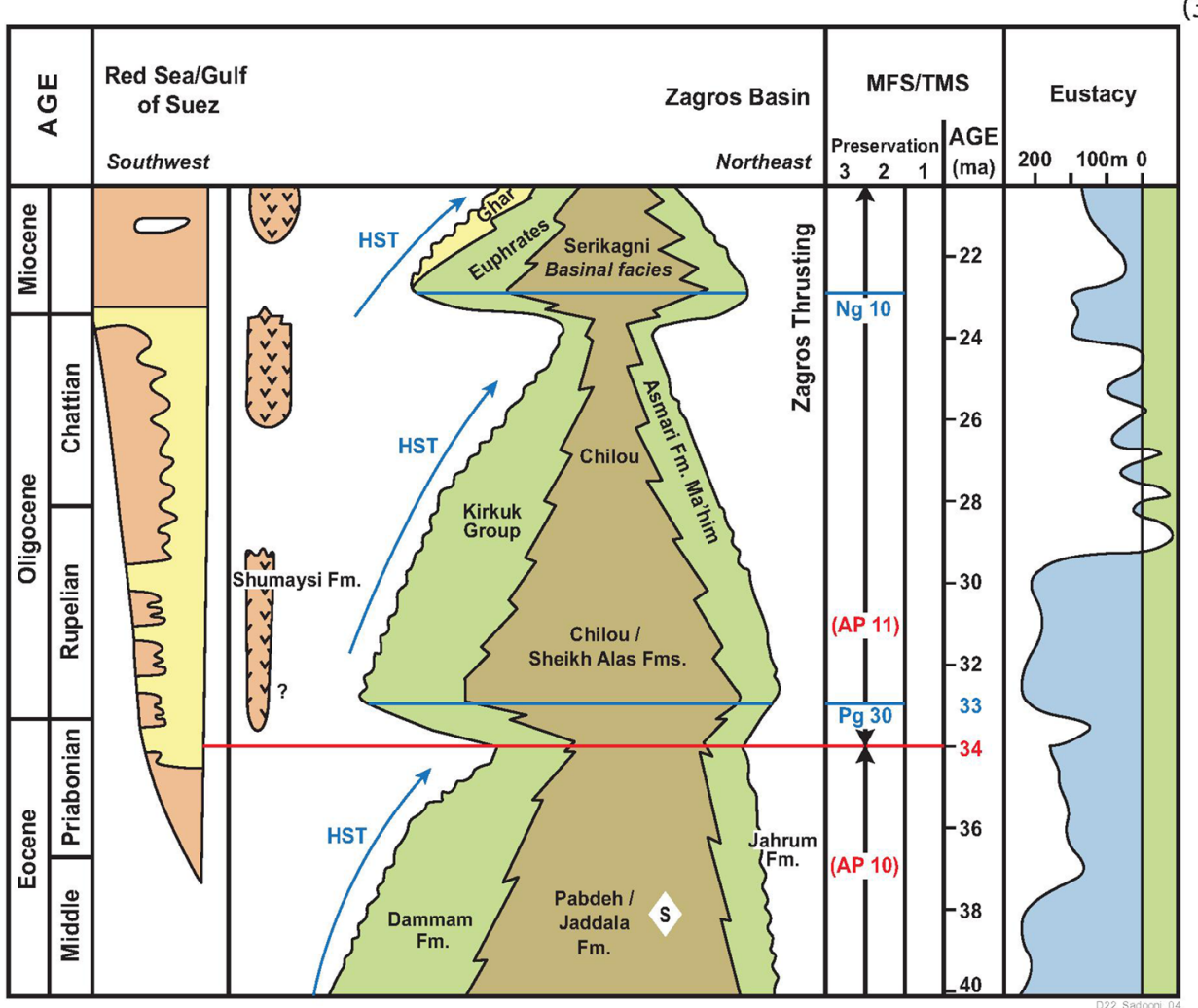

and laterite were also found in Iraq and Yemen. In north Oman mixed carbonate and clastic sediments were deposited within the Taqa Formation and deep-water carbonates were encountered in Dhofar region to the south. Wide-spread erosion or non-deposition were also characteristic features of this period in many parts of the Arabian Plate. These sediments are missing in large parts of southern Iraq, Jordan, Kuwait, Bahrain, Qatar, major parts of eastern Saudi Arabia and, some parts of the UAE.

Following is description of the main Oligocene sediment types located at different parts of the Arabian basin. It must be stressed that there are currently two problems associated with the description of the Oligocene strata. Firstly, they are not well-documented in many parts of the Arabian Basin; secondly, they are often not differentiated from the overlying and underlying Eocene and Miocene sediments. Therefore, the following review is based on the available data and may change significantly if more data becomes available in the future.

\section{Flysch sediments}

Some parts of the Naopurdan Group of northern Iraq may belong to the Oligocene. This rock is formed of grey shales with thin green greywackes that have been described as representative of fine rhythmic flysch. The shales also contain some pebbles of basic volcanics, lenticular limestones and sills of basic volcanic materials associated with reddish mudstone, jaspers, limestones and, radiolites. These pebbles were supposed to have been deposited in deep depressions at the foothills of the newly rising Zagros mountains (Buday 1980; Jassim and Goff 2006). Similar flysch deposits were reported from Dhofar province along the southeastern coasts of Oman in the Taqa Formation which is composed of up to $1400 \mathrm{~m}$ of calcareous, slightly glauconitic, green-grey silt and fine sand (Beydoun and Greenwood 1968; Hawkins et al. 1981). These sediments were probably deposited in the deeper parts of the Oligocene basin, at the margins of the rising mountains (Fig. 2).

\section{Bathyal sediments}

In west Iran, the Pabdeh Formation (Paleocene-Oligocene) consists of around $1000 \mathrm{~m}$ of monotonous sequence of grey marls containing rich planktonic fauna with marly argillaceous limestones, that was deposited in a deep euxinic and outer ramp setting. During the Oligocene, the Ras AlKhaimah sub-basin of the UAE was a still-subsiding part of the old Cretaceous basin. The sediments there are composed of a bathyal, sequence of rhythmically bedded argillaceous limestone and chert. The Pabdeh of Ras Al-Khaimah subbasin is similar to the Iranian section of the Zagros Basin, 
except that the basal purple shale is absent and replaced by marl and argillaceous limestone. It is formed of approximately $1500 \mathrm{~m}$ of interbedded hemipelagic limestone. Marl, calcareous shale and clay sediments are found in areas more to the offshore (Alsharhan and Nairn 1997). These strata represent the deeper parts and, the outer ramp part of the Oligocene carbonate basin.

\section{Red beds}

The red beds consist of purplish to red clastics such as siltstone and sandstone associated with tuffaceous materials. Such sediments were described by Buday (1980) in the extreme northern parts of the Arabian Plate beyond the documented Oligocene basin. In the Amadiya area, northern Iraq, Oligocene fossils were reported in a suite of red and green marlstone and siltstone. These findings were confirmed by Ctyroky 1971 in an unpublished report (cited by Buday 1980). Also, Hall 1957 described a tuffaceous complex in a report cited by Buday (1980), near the area of Sinia, east of the city of Amadiya. This unit is termed the Sinia Tuffs and believed to be of Oligocene-Miocene age. Buday (1980) suggested adding these red beds to the Suwais Group (Bolton 1958 unpublished report cited by Buday 1980) which had been described from the whole Imbricated Zone in the extreme northeastern parts of northern Iraq. This latter group is a complex unit formed of different rock assemblages with many breaks in sedimentation that range in age from the Late Maastrichtian till the Oligocene.

The red bed sediments referred to are similar to the Paleocene-Eocene sediments of the Gercus and Kolosh formations of northern Iraq. They are believed to be continental clastics filling depressions that resulted from crustal shortening and other tectonic deformation in the area.

On the western side of Arabia, red bed sediments were described in the Matiyah Formation in the Red Sea region of Saudi Arabia. The Matiyah Formation consists of purplishred siltstone and sandstone and is associated with basalt flow in some locations. Alsharhan and Nairn (1997) suggested that these siltstone and sandstone sediments belong to the Early Oligocene and were laid down in a fluvial-lacustrine setting.

\section{Volcanic and pyroclastic sediments}

Volcanic materials were reported within Oligocene sediments from scattered sites within the Arabian Basin. In the Imbricated and Zagros Thrust zones of northeastern Iraq, Buday (1980) described the Naopurdan Shaly Series to be of Eocene and Oligocene in age. This series consist of abundant volcanic layers found either as lavas or, pyroclastic and tuffaceous rocks.
Dating of the Harrat Ash Shaam basalt volcanic field in the northeastern part of Jordan using $\mathrm{K}-\mathrm{Ar}$ suggested the presence of three main episodes of volcanic activity in the region: Oligocene to Early Miocene (26-22 Ma); Middle to late Miocene (13-6 Ma); and, Pliocene to Pleistocene (5 to less than 0.5 Ma) (Tarawneh et al. 2000). Basaltic flows were also described in the Matiyah Formation in western Saudi Arabia. These volcanics are believed to be associated with the opening of the southern part of the Red Sea that occurred during the Late Oligocene. The term "Yemen volcanics was adopted by Grolier and Overstreet (1978) to describe the volcanic material in the northern parts of the Yemen, which is equivalent to the Aden Trap Series. The term "Yemen volcanics" was suggested by Greenwood and Bleakley (1967) to describe similar volcanic materials in the southern parts of the country. These wide-spread volcanisms were also probably related to the development of the Red Sea. They are the result of dykes and fissure-type volcanism that may attain a thickness of around $1500 \mathrm{~m}$ and, cover an area of $45,000 \mathrm{~km}^{2}$. They consist of tuffs, shales, coal interbeds, limestones and, pillow lavas with paleosols at the top.

\section{Continental clastic facies}

Continental clastics were also described in some parts of the Arabian Basin. In the fields of Abu Gherab and Fuqa, along the Iraq-Iran border, Al-Siddiki (1980) documented a mixed carbonate-clastic succession from the so-called "Mesan Group". These clastics are porous and permeable sandstones that form the lower parts of the Oligocene carbonates in that region that were probably laid down under fluvial or lacustrine conditions. Similar units are also found within the lower parts of the Asmari Formation in some of the oilfields, across the border in Iran.

The sandstones of the Ahwaz Member of the Asmari Formation in the Dezful embayment are classified as quartzarenite, sub-litharenite and subarkose types. These sandstones contain quartz, feldspar and fragments of sedimentary and metasedimentary rocks of re-cycled orogen and craton interior tectonic provenance. Tectonic setting of these sandstone suggests a quartzose sedimentary provenance within a passive continental margin. Their source area underwent intense recycling but a moderate degree of chemical weathering and, they are consistent with a semiarid climate and low-relief highlands (Jafarzadeh and Hosseini-Bartzi 2008).

Other continental sediments were described by Alsharhan and Nairn (1997) from water wells northeast of the Azraq, west of the city of Irbid in Jordan. Marl beds containing limonitic nodules were found interbedded with massive limestones. These marl sediments were probably formed in freshwater lakes that occupied the rift system. Wilhelm (1971) described some fish remains from the Oligocene or 
Miocene sediments of Wadi Araba Graben in south Jordan and suggested the presence of fresh water sediments accordingly.

\section{Carbonates facies}

There are three areas in which Oligocene carbonates are known to have developed fully. These are Kirkuk, Bai Hassan fields in the Qara Chauq Dagh Mountains in northern Iraq and, the Asmari Formation in Hafit Mountain along the border of the UAE with Oman together with the same formation in southwestern Iran.

In northern Iraq, van Bellen (1956) suggested that the Oligocene carbonates may be divided into three cycles of lower, middle and upper Oligocene. Each cycle is formed of basinal (offshore), fore-reef and reef and back-reef facies. $\mathrm{He}$ assigned formation names for each of these facies within each cycle. Later researchers, however, called attention to the difficulties associated with the recognition of these cycles in the subsurface section due to the lack of distinctive boundaries between them. Many later researchers (e.g. Buday 1980; Majid and Veizer 1986) also suspected the validity of such tripartite vertical and horizontal divisions. Al-Qayim and Khwaika (1980) suggested that the Oligocene sequence consists of only two reef cycles, each consisting of three facies. Their interpretation was that back-reef/reef facies are formed of skeletal lime wackestone to packstone, fore-reef facies are formed of dolomitized skeletal wackestone and, basinal facies are represented by detrital skeletal lime wackestone and dolomitized marly lime packstone. AlSakini (1992) indicated that areal distribution of these sediments does not support this vertical subdivision either. He noted that the sediments of the lower and middle Oligocene cycles with their full facies are found only in the Baba dome of Kirkuk Field, as well as in the parts of Avana dome neighboring it. The Bai Hassan Field contains only parts of the lower cycle and, most parts of the middle cycle, as well as the Anah Formation which belongs to the upper Oligocene. The Khurmala dome and most parts of the Avana dome of Kirkuk Field and the neighboring Jambur Field have none of the Oligocene sediments. Majid and Veizer (1986) studied the main facies forming these sediments and suggested that the Oligocene sediments in Kirkuk Field represent a homoclinal ramp that evolved into a rimmed shelf. They attributed the facies repetition to the existence of faults as is the case in the Kirkuk-163 well. The different microfacies of Kirkuk Group are shown in Fig. 6 and in Table 2.

The Oligocene sediments also crop out in Jabal Hafit close to the Oman Mountains and have a thickness of up to $480 \mathrm{~m}$ being assigned to the Asmari Formation. This formation is formed of silty and gypsiferous marl with conglomerate at the lower part, it grades upward into thickly bedded, algal coral nummulitic limestone and, is capped by poorly bedded, marly foraminiferal limestone and marly oolitic and bioclastic limestones. These sediments and the fauna they contain suggest deposition took place in a deep outer shelf. Quiet-water lagoons supplied peloids to the back reef, reef and fore-reef facies as well as to the shallow open marine facies of the inner shelf. Samples of these microfacies are shown in Fig. 6 and detailed in Table 3 (Whittle et al. 1995).

Offshore in the UAE, where more information has been gathered from the subsurface, the Asmari Formation reaches up to $110 \mathrm{~m}$ and can be divided into three lithologic units. The lower unit consists of nummulitic and dolomitic limestones, dolomites with silty mudstone and anhydritic nodules. The middle unit is mainly intraclastic and nummulitic packstone and grainstone and calcareous mudstone, whereas, the upper unit is composed of silty dolomite, pelletal and dense in part, interbedded with pelletal limestone. The Asmari is overlain conformably by early Miocene sediments and the base rests conformably on the late Eocene Dammam Formation.

The Asmari Formation of west and southwest Iran was deposited on a carbonate ramp contrary to deposition of the age-equivalent Kirkuk Group which has well-developed shelfal coral reef (Fig. 7). The inner ramp carbonates of the formation consist of large benthic foraminifera-bearing limestone such as nummulites and Lepidocyclina. The middle ramp also formed of foraminiferal limestone but is mixed with other fossil assemblages such as red algae, echinoderms and bryozoans. The outer ramp is similar to the basinal facies of Kirkuk Group and consists of wackestone and mudstone containing planktonic foraminifera mixed with large foraminifera (Shahkarami et al. 2013; Avarjani et al. 2015; Roozpeykar and Moghaddam 2016).

Dill et al. (2018) described some coral-bearing limestone that was deposited in a flat-topped open shelf in the northern margin of the Asmari intra-shelf basin of southwest Iran.

\section{Oil potential}

The eternal fire of Kirkuk, which is believed to have been ignited before the beginning of written history, is the clearest manifestation of the shallow and rich Oligocene petroleum deposits in northern Iraq. The Oligocene strata host some of the richest, early discovered hydrocarbon deposits of the region because that include large reserves found in the fields of southwest Iran and Northeast Iraq. These reserves are hosted in the "Main Limestone" reservoir of Kirkuk Field and the Lower Asmari Formation in the fields of southwestern Iran. The fractures play an important role in porosity and permeability creation, and most of the Asmari Formation in SW Iran produces mainly via fractures due to the generally 
Fig. 6 Main microfacies of the Oligocene carbonates in the Arabian Plate. a Basinal to sub-basinal facies formed of dwarf small foraminifera with thin shells from the Asmari Formation, near Al-Ain City, UAE. b Coral fragment forming a part of coral framestone from the Oligocene Kirkuk Group in Qara Chauq Mountain, near Kirkuk City, northern Iraq. c Reef- to fore reef sediments formed of Large benthic foraminifera associated with red coralline algae from the Asmari Formation, near AlAin City, UAE. d Fore-reef facies made up of nummulites grainstone from the Asmari Formation, near Al-Ain City, UAE. e, f Lagoonal and back reef facies formed of packstone to grainstone of small benthic foraminifera from Kirkuk Group, Qara Chauq Mountain, near Kirkuk city, northern Iraq
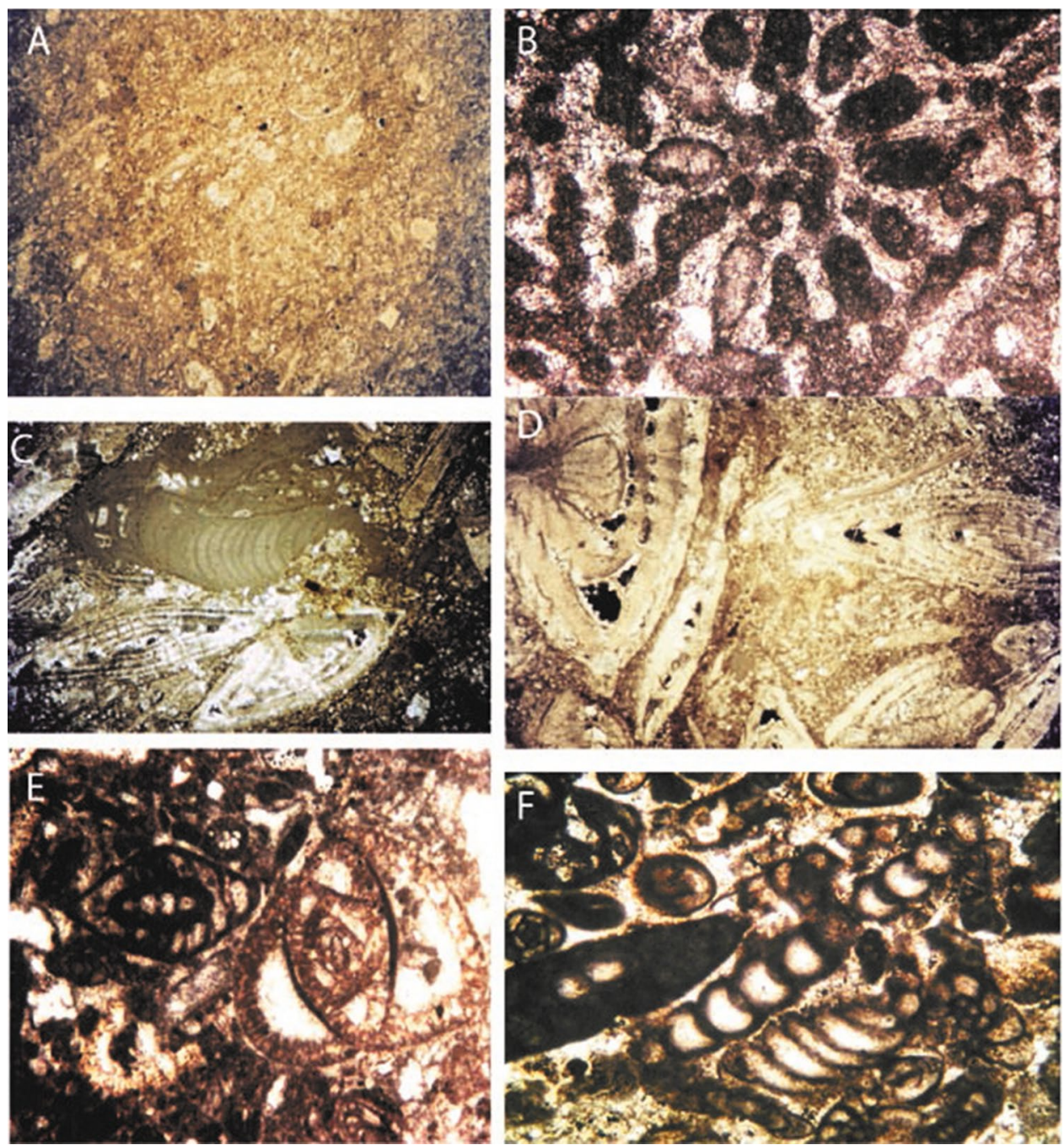

tight matrix of the Formation (McQuillan 1985; Ahmadhadi et al. 2008).

The Kirkuk, Bai Hassan, Jambur and many other fields of northeastern Iraq produce major amounts of hydrocarbons from the Oligocene reefal and shallow carbonate facies of the Kirkuk Group, which are partially equivalent to the Asmari facies (Daniel 1954; Dunnington 1958). The supergiant Kirkuk Field is located in the Zagros Foreland Fold Belt. It is more than $95 \mathrm{~km}$ long and around $10 \mathrm{~km}$ wide. The Kirkuk structure is composed of a sinuous anticline which is divided by two saddles into three major domes (van Bellen 1956). It is flanked to the southwest by the Bai Hassan and Jambur fields.

Much of the production of the three fields is derived from two cycles of the Oligocene shelf margin reefs (Alsharhan and Nairn 1997; Al-Qayim and Khwaika 1980). A third but non-producing cycle is exposed at the surface in the Qarah Chauq Dagh anticline to the southwest. Seal is provided by the overlying Lower Fars Formation which is composed of a basal conglomerate and overlying evaporitic-carbonate sequence. Hydrocarbons are generally interpreted to have been derived from pre-existing Middle Cretaceous paleoreservoirs which were breached during the Zagros folding (Dunnington 1958). The axes of the Kirkuk and associated structures in the Zagros trend are superimposed diagonally across the Eocene and Oligocene shelf margin facies belts.

The producing Kirkuk Group reef cycles are divided into back reef/reef, fore-reef, and basinal facies by their sedimentary components and petrophysical characteristics. The entire suite of carbonate lithofacies, from proximal basin slope to inner lagoonal produces hydrocarbons at the Kirkuk and adjacent fields but each for a different reason with each being of different importance. The carbonate mud-prone reef framework and lagoonal facies have little remnant primary porosity but, their pervasive cementation and lack of clay content make the dense carbonates highly fracture prone in the crestal and upper flank areas of the producing structures. Back-reef and reef core facies of both cycles are considered as a single unit because both facies consist of white, very dense, poorly porous wackestone to packstone which 


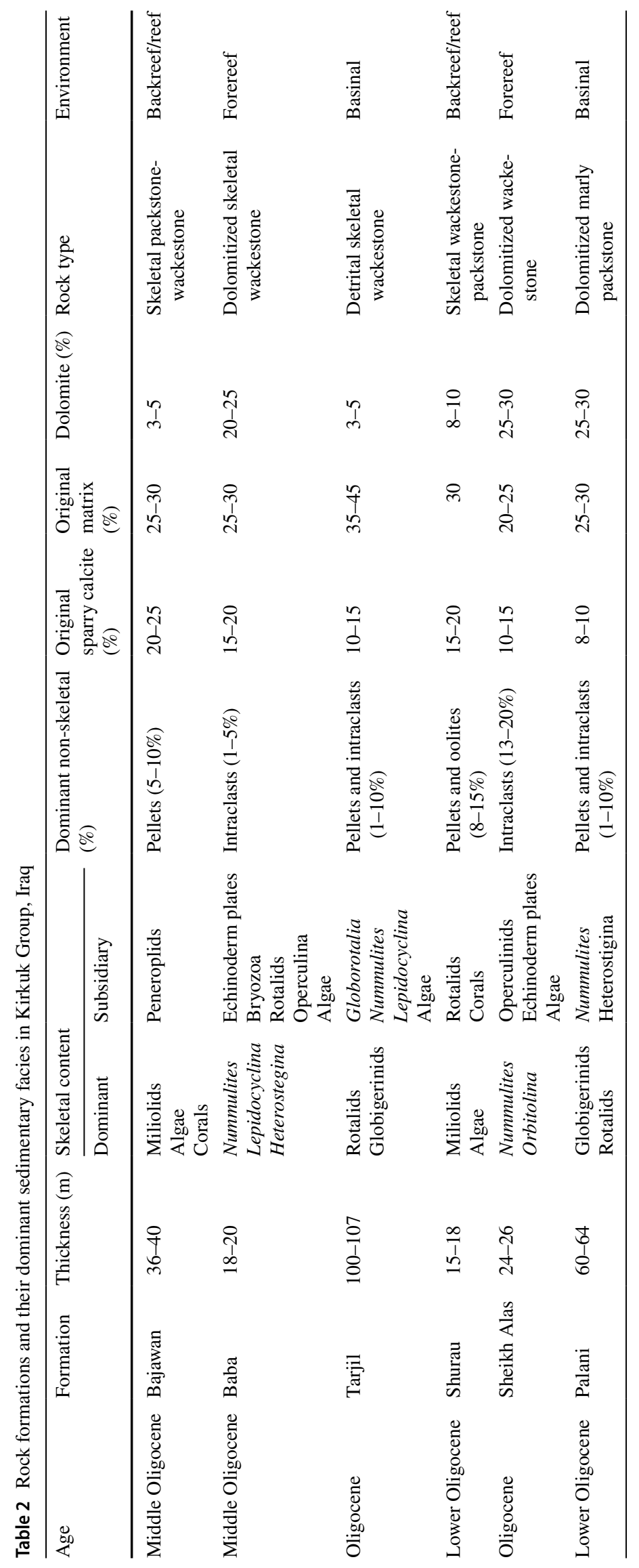


Table 3 Sedimentary facies of the Early-Middle Oligocene Asmari Formation, Abu Dhabi (UAE)

\begin{tabular}{|c|c|c|}
\hline Facies & Description & Depositional setting \\
\hline Nummulitic Packstone & $\begin{array}{l}\text { Almost exclusively composed of Nummulites sp. } \\
\text { with rare miliolids, peneroplids, echinoderm frag- } \\
\text { ments and peloids }\end{array}$ & Restricted shallow shelf \\
\hline $\begin{array}{l}\text { Foraminiferal Wackestone/Packstone } \\
\text { (greater percentage of non-Nummulitic } \\
\text { forams) }\end{array}$ & $\begin{array}{l}\text { Miliolids, peneroplids and Nummulites sp. in } \\
\text { approximately equal proportions with subordinate } \\
\text { echinoderm fragments and rare red algae and non- } \\
\text { skeletal peloids }\end{array}$ & Slightly restricted, shallow shelf \\
\hline Echinoderm/Red Algal Packstone & $\begin{array}{l}\text { Dominated by echinoderm fragments/spines and } \\
\text { red algae (primarily Goniolithon), but miliolids, } \\
\text { peneroplids and Nummulites sp. are common and } \\
\text { sometimes equal in density; rare peloids }\end{array}$ & Open marine, shallow shelf \\
\hline Coral Framestone & Exclusively composed of broken coral fragments & High-energy reef or fore-reef \\
\hline Peloidal Packstone & Non-skeletal; consists of bimodal peloids & Low-energy back-reef \\
\hline Mudstone/Wackestone & $\begin{array}{l}\text { Micrite matrix; sparse peloids are common; virtu- } \\
\text { ally devoid of species; rare thin-walled bivalves, } \\
\text { miliolids }\end{array}$ & Deep, outer shelf, quiet-water lagoon \\
\hline Dolomite & $\begin{array}{l}\text { Peloids engulfed in rhombs suggest these were origi- } \\
\text { nally peloidal packstones }\end{array}$ & Forms post-depositionally in meteoric setting \\
\hline
\end{tabular}

Fig. 7 Main depositional environments of the Asmari Formation in Iran and Iraq (Modified after Soltani et al. 2013)

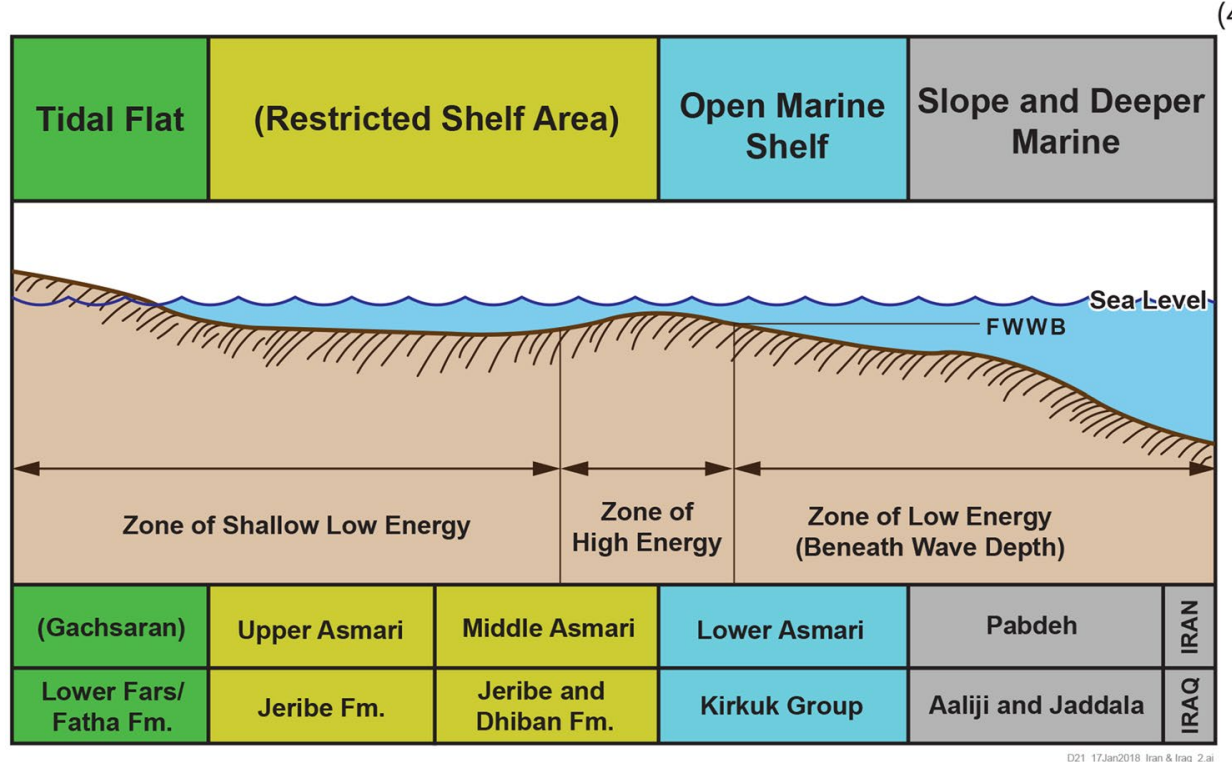

according to Daniel (1954) have less than 1-4\% matrix porosity and less than $1-5 \% \mathrm{mD}$ permeability. Although lacking primary porosity, these tight rocks are extensively fractured and they produce from fractures in wells along the crest in the northern half of the Baba dome and into the Amshe saddle, similar to the fractured lagoonal facies of the Asmari Formation in the Iranian Zagros fields. Matrix porosity is estimated by Daniel (1954) to be $4-10 \%$ where the muddy carbonates are recrystallized and lightly dolomitized. In the Shurau Formation (1st cycle), Daniel (1954) reported that the matrix porosity in the chalky hemipelagic limestone is between $8-18 \%$ with permeabilities of less than
1-10 $\mathrm{mD}$. The dolomitized basinal and fore-reef facies are about 100 times more permeable than the unaltered basinal facies matrix. Hydrocarbon producibility of the unaltered basinal limestones is enhanced by their thin-bedding and the presence of abundant joints.

The fore-reef talus apron, however, has enough remnant primary porosity and permeability in the updip, nondolomitized facies to serve as an adequate reservoir rock. Excellent reservoir characteristics of 30-35\% porosity and 500-1000 $\mathrm{mD}$ permeability result from the pervasive replacement of the skeletal packstones by a sucrosic 
dolomite mosaic that contain large amounts of interconnected intercrystalline pore volumes.

The Asmari Formation serves as the main reservoir for most of the oil produced in the Zagros foothills structural trend, although matrix porosity of the limestone is typically less than $5 \%$ and may be less than $1 \%$ in many of the producing wells. The Asmari produces from pervasive fracture porosity and permeability confined to the axial zones of the anticlines. What little remnant primary porosity that remained after early diagenesis has been occluded by pervasive sparry calcite cementation.

Al-Gailani (1999) suggested the potential presence of a Miocene/Oligocene reservoir in the Halfaya, Abu Gherab and Fuqa fields along the border with Iran in southeast Iraq. The Oligocene strata in these fields contain two porous and permeable sand units. No much data is available on the reservoir characteristics of these sediments.

In Syria, the Chilou Formation (Lower Oligocene) is composed of around $350 \mathrm{~m}$ of shelfal carbonates with dolomite. The gross thickness of the reservoir unit is around 320 $\mathrm{m}$. The Formation has a medium porosity and fracture permeability. It has produced oil and gas from several fields such as Gbeibe, Ghouna, Salhieh and Sheikh Mansour and gas only from the Margada Field (Alsharhan and Nairn 1997).

Heavy oil accumulation ( $24^{\circ}$ API gravity) occurs in the Asmari Formation in Mandous Field (offshore Abu Dhabi) (Alsharhan and Nairn 1997).

Future exploration of the oil potential these strata should focus on finding more of the basin-margin buildups that survived extensive erosion and, that possess the required entrapment mechanisms. Furthermore, clastic strata in some deeper parts of the basin may also represent future exploration targets.

\section{Conclusions}

1. The Oligocene was the epoch in which global climate transitioned from warm "greenhouse" to the cooler "icehouse" which persists until the present day.

2. The Oligocene marked the start of Antarctic glaciation which was associated with decline in water temperature, salinity, nutrient supply, oxygen levels and the extinction of some fauna and flora.

3. In the study area, the Oligocene witnessed the shrinkage of the Neotethys and the development of the Paratethys, collision of the Arabian and Eurasian Plates, exhumation of parts of the Arabian Plate, evolution of the Zagros mountains and the opening of the Red Sea and the Gulf of Aden.
4. Most of the Oligocene sediments are absent in major parts of the Arabian Plate but they are well-preserved in south and southwestern Iran.

5. The whole Oligocene succession represents the lower part of the AP11 megasequence. The MFS Pg30 has been identified in some parts of the Arabian Plate and Iran.

6. The most important Oligocene sediments are the coral reefs of Kirkuk Group, northern Iraq and the shallow marine carbonates of the Asmari Formation in western Iran.

7. The study area was the birthplace of the commercial oil production in the Middle East at the first decade of the last century from Masjid-i-Sulaiman Field in Iran and Kirkuk Field in Iraq.

8. Exploration of future hydrocarbon potential should focus on identifying any remaining coral buildups or clastic strata that are equivalent to the Asmari Formation in Iran.

Acknowledgements Open Access funding provided by the Qatar National Library. The manuscript benefited from major amendments by two anonymous reviewers of Carbonates and Evaporites. David Marioni (UTM) revised the original manuscript.

Open Access This article is distributed under the terms of the Creative Commons Attribution 4.0 International License (http://creativeco mmons.org/licenses/by/4.0/), which permits unrestricted use, distribution, and reproduction in any medium, provided you give appropriate credit to the original author(s) and the source, provide a link to the Creative Commons license, and indicate if changes were made.

\section{References}

Ahmadhadi F, Daniel JM, Azzizadeh M, Lacombe O (2008) Evidence for pre-folding vein development in the Oligo-Miocene Asmari Formation in the Central Zagros Fold Belt, Iran. Tectonics. Am Geophys Union (AGU) 27:1-22

Al-Gailani MB (1999) Halfaya field: a twenty-first century super giant. In: AAPG international conference and exhibition, Birmingham, England, Sept 1999 (abstract)

Al-Qayim B, Khwaika M (1980) Depositional environment and diagenesis of the Oligocene reef cycles, Kirkuk Oil Field, northern Iraq. Mod Geol 7:177-190

Al-Sakini J (1992) Summary of the petroleum geology of Iraq and the Middle East. Naft Al-Shamal Press, Kirkuk (in Arabic)

Alsharhan AS, Nairn AEM (1997) Sedimentary basins and petroleum geology of the Middle East. Elsevier, Amsterdam

Al-Siddiki A (1980) Mesan Group a new Oligocene stratigraphic unit in southern Iraq. In: 26th international geologic congress, Paris (abstract)

Aqrawi AMA, Goff JC, Horbury AD, Sadooni FN (2010) The petroleum geology of Iraq. Scientific Press, London

Avarjani S, Mahboubi A, Moussavi-Harami R, Amiri-Bakhtiar H, Brenner R (2015) Asmari Formation in Marun oilfield, North Dezful Embayment, Zagros Basin, SW Iran. Palaeoworld $24: 336-358$ 
Beydoun ZR (1988) The Middle East: regional geology and petroleum resources. Scientific Press, London

Beydoun ZR, Greenwood JEW (1968) Aden Protectorate and Dhofar: Lexique Stratigraphique International, Fascicule 10b2. Centre national De La Recherche Scientifique, Paris

Bolton CMG (1958) The geology of the Ranya area. Site Investigation report, State Organization of Minerals (SOM) Library, 271, Baghdad, Iraq

Buday T (1980) The regional geology of Iraq, 1, Stratigraphy and Paleogeography. Dar Al-Kutub Publishing House, Mosul

Cotton LJ, Pearson PN (2011) Extinction of larger benthic foraminifera at the Eocene/Oligocene boundary. Palaeogeogr Palaeoclimatol Palaecol 311:281-296

Daniel EJ (1954) Fractured reservoirs of Middle East. Am Assoc Pet Geol Bull 38:774-815

Dill MA, Vaziri-Moghaddan H, Seyrafian A (2018) Oligo-Miocene carbonate platform evolution in the northern margin of the Asmari intra-shelf basin, SW Iran. Mar Pet Geol 92:437-461

Dunnington HV (1958) Generation, migration, accumulation and dissipation of oil in northern Iraq. In: Weeks LG (ed) Habitat of oil. AAPG, Tulsa, pp 1194-1251

Ellis AC, Kerr HM, Cornwell CP, Williams DO (1996) A tectonostratigraphic framework for Yemen and its implications for hydrocarbon potential. Pet Geosci 2:29-42

Farouk S, Ahmad F, Smadi AA (2013) Stratigraphy of the middle Eocene-Lower Oligocene successions in northwestern and eastern Jordan. J Asian Earth Sci 73:396-408

Greenwood JEG, Bleakley D (1967) Geology of the Arabian Peninsula, Aden Protectorate. USGS Professional paper, 560-C

Grolier MJ, Overstreet WC (1978) Geologic map of the Yemen Arab Republic (Sana'a). USGS, Scale 1:500,000, map I-1143-B

Habibi T, Ruban DA (2017) The Oligocene carbonate platform of the Zagros Basin, SW Iran: an assessment of highly-complex geological heritage. J Afr Earth Sci 129:675-682

Hawkins TRW, Hindle D, Strugnell R (1981) Outlines of the stratigraphy and structural framework of southern Dhofar (Sultanate of Oman). Geol En Mjin 60:247-256

Houben AJP, van Mourik CA, Montanari A, Coccioni R, Brinkhuis $\mathrm{H}$ (2012) The Eocene-Oligocene transition: changes in sealevel, temperature or both? Palaeogeogr Palaeoclimatol Palaecol 335:75-83

Hughes-Clarke MW (1988) Stratigraphy and rock unit nomenclature in the oil producing area of interior Oman. Jour Petrol Geol 11:5-60

Ivany LC, Patterson WP, Lohmann KC (2000) Cooler winters as a possible causes of mass extinctions at the Eocene/Oligocene boundary. Nature 407:887-890

Jafarzadeh M, Hosseini-Bartzi M (2008) Petrography and geochemistry of Ahwaz Sandstone Member of Asmari Formation, Zagros, Iran: implications on provenance and tectonic setting. Revista Mexicana de Ciencias Geologicas 25:247-260

James GA, Wynd JG (1965) Stratigraphic nomenclature of the Iranian Oil Consortium Agreement Area. AAPG Bull 49:2182-2245

Jassim SZ, Goff J (2006) Geology of Iraq. Dolin, Prague and Moravian Museum, Brno

Jones RW, Racey A (1994) Cenozoic stratigraphy of the Arabian Peninsula and Gulf. In: Simmons MD (ed) Micropaleontology and hydrocarbon exploration in the Middle East. Chapman and Hall, London, pp 273-307

Kargaranbafghi F, Neubauer F (2017) Tectonic forcing to global cooling and aridification at the Eocene-Oligocene transition in the Iranian Plateau. Glob Planet Change 171:248-254

Lees GM (1933) Reservoir rocks of Persian oil wells. Am Assoc Pet Geol Bull 17:224-240
Li S, Xing Y, Valdes PG, Huang Y, Su T, Farnsworth A, Lunt DJ, Tang H, Kennedy A, Zhou Z (2018) Oligocene climate signals and forcings in Eurasia revealed by plant macrofossils and modelling results. Gondwana Res. https://doi.org/10.1016/j. gr.2018.04.015

Majid AH, Veizer J (1986) Deposition and chemical diagenesis of Tertiary carbonates, Kirkuk Oil Field, Iraq. AAPG Bull 70:898-913

Maravelis A, Zelilidis A (2012) Paleoclimatology and paleoecology across the Eocene/Oligocene boundary, Thrace Basin, Northeast Aegean Sea, Greece. Palaeogeogr Palaeoclimatol Palaeoecol 365-366:81-98

McQuillan H (1985) Fracture controlled production from the OligoMiocene Asmari Formation in Gachsaran and Bibi Hakimeh fields, southwest Iran. In: Roehl PO, Choquette PW (eds) Carbonate petroleum reservoirs. Springer, New York, pp 513-523

Motiei H (1993) Stratigraphy of Zagros. Geological Survey of Iran, Tehran

Ozsvárt P, Kocsis L, Nyerges A, Győri O, Pálfy J (2016) The EoceneOligocene climate transition in the Central Paratethys. Palaeogeogr Palaeoclimatol Palaeoecol 459:471-487

Prothero DR (1994) The Eocene-Oligocene transition, Paradise Lost. Critical moments in paleobiology and earth history series, Xviii. Columbia University Press, New York

Richardson RK (1924) The geology and oil measures of southwest Persia. J Inst Pet Technol 10:256-283

Roger J, Platel JP, Cavelier C, Bourdillon-de-Grisac C (1989) Donne'es nouvelles sur la stratigraphie et l'histoire ge'ologique du Dhofar (Sultanat d'Oman). Bull Soc Geol Fr 2:265-277

Rögl VF (1998) Paleogeographic considerations for Mediterranean and Paratethys Seaway (Oligocene to Miocene). Ann Naturhist Mus Wien 99A:279-310

Roozpeykar A, Moghaddam IM (2016) Benthic foraminifera as biostratigraphical and paleoecological indicators: an example from Oligo-Miocene deposits in the SW of Zagros basin, Iran. Geosci Front 7:125-140

Sarkar A, Sarangi S, Ebihara M, Bhattacharya SK, Ray AK (2003) Carbonate geochemistry across the Eocene/Oligocene boundary of Kutch, western India: implications to oceanic $\mathrm{O}_{2}$-poor conditions and foraminiferal extinction. Chem Geol 201:281-293

Shahkarami MH (2013) Microfacies correlation analysis of the Oligocene-Miocene Asmari Formation in the central part of the Rage-Safid anticlinal oil field, Zagros Basin, south-west Iran. Turk J Earth Sci 22:204-219

Sharland PR, Archer R, Casey DM, Davies RB, Hall S, Heward A, Horbury A, Simmons MD (2001) Arabian plate sequence stratigraphy. GeoArabia Special Publication, 2, Gulf Petrolink, Bahrain

Shirazi MP, Nezhad MD, Ghalavand H (2012) Microfacies and sedimentary environment of the Oligo-Miocene sequence (Asmari Formation) in Khuzestan sub-basin, Zagros Basin, southwest Iran. Int Res J Geol Min 2:16-24

Soltani B, Rahimpour-Bonab H, Ranjbaran M (2013) Regional stratigraphic correlation and comparison of the Oligo-Miocene deposits in Dezful (SW Iran) and Kirkuk (N and NE Iraq) embayments. J Zankoy Sulaimani Part A 15:77-93

Tarawneh K, Ilani S, Rabba I, Harlavan Y, Peltz S, Ibrahim K, Weinberger R, Steinitz G (2000) Dating of Harrat Ash Shaam basalts, Northeast Jordan (Phase 1). Geological Survey of Israel, Jerusalem

van Bellen RC (1956) The stratigraphy of the "Main Limestone" of the Kirkuk, Bai Hassan and Qarah Chauq Dagh structures in North Iraq. J Inst Pet 42:233-263 
van Bellen RC, Dunnington HV, Wetzel R, Morton DM (1959) Lexique Stratigraphique International, Fascicule 10a, Iraq. Centre national De La Recherche Scientifique, Paris

Wade B, Pearson PN (2008) Planktonic foraminiferal turnover, diversity fluctuations and geochemical signals across the Eocene/Oligocene boundary in Tanzania. Mar Micropaleontol 68:244-255

Whittle GL, Alsharhan AS, El Deeb WMZ (1995) Bio-lithofacies diagenesis in the Early-Middle Oligocene of Abu Dhabi, UAE. Carbonates Evaporites 10:54-64
Wilhelm W (1971) Fischfunde aus dem Tertiae des Wadi Araba-Grabens in Jordanien. Geol Jahrb 89:193-201

Publisher's Note Springer Nature remains neutral with regard to jurisdictional claims in published maps and institutional affiliations. 